\title{
Economic Regionalism in Africa: A Study of Eccas (Economic Community of Central African States)
}

\author{
Prof.Dr. Nurettin Can ${ }^{1}$, Abubakar Aliyu Maigari ${ }^{2}$ \\ 1,2 Nile University of Nigeria
}

\begin{abstract}
Regional economic communities in Africa started in 1960s which was encouraged by the United Nations in order to have single economies as regional systems. To achieve this goal, the African Union emphasized on the development of institutions within the organization. Decades later, African countries learnt from the European Union model the importance of regional economic integration. This paper tends to evaluate the institutional arrangements of the Economic Community of Central African States (ECCAS) designed to facilitate in getting things move freely across the region such as goods and services as well as regulating economic policies among the countries within the region. We tried to find out whether ECCAS as a regional economic community has been successful in copying the European Union model. We would observe the objectives of ECCAS, its performance within the region, and the challenges faced. The study is essentially narrative, qualitative and historical relying on secondary data as method of data collection, and qualitative-descriptive method of data analysis.
\end{abstract}

Keywords: Economic recession, market power, firm's performance

\section{Introduction}

The dawn of regional economic communities (RECs) in Africa can be traced back to the 1960s, when the United Nations Economic Commission for Africa (UNECA) encouraged African states to incorporate single economies into sub regional systems with the ultimate objective of creating a single economic union on the African continent. In order to realize this aim, the Organization of African Unity (OAU, predecessor of the African Union, $A U$ ) identified the need to enhance regional integration within the organization, recognizing that each country on its own would have little chance of, inter alia, attracting adequate financial transfers and the technology needed for increased economic development (Hansohm \& Shilimela, 2006). Years after attaining independent African 
leaders understood the need to cooperate in order to achieve a more sustainable economic that will be beneficiary for countries under the economic community.

Economic Community of Central African States (ECCAS) was established in 1985 by ten founding states, namely, Burundi, Cameroon, Central African Republic, Chad, Democratic Republic of the Congo, Republic of the Congo, Equatorial Guinea, Gabon, Rwanda, Sao Tome and principle, while Angola joined in 1999(Aniche et al., 2009).

A prominent scholar Meyer (2011) averred that the founding treaty of 1983 foresees the establishment of a single regional market, including the abolition of tariff and non-tariff barriers; establishing a common external customs tariff and common trade policy towards third countries; progressive achievement of the free movement of persons, goods, services and capital; as well as harmonization of national policies in a number of fields, such as industry, transport, energy and agriculture. However, despite the proliferation of regional economic groups in Africa, intra-regional trade between African countries and especially between members of the same economic unions is limited. Countries belonging to various economic blocs have taken limited measures in fully reducing tariffs and eliminating non-tariff barriers, and in adopting common economic policies that promote growth and these tend to impede meaningful economic integration that foster trade between member states (Ntembe \& Tawal, 2012).

In a report by NEPAD (New Partnership for Africa's Development, 2015), the region is believed to be abounds with huge highly valued oil, mineral and mining resources. Recently, proven oil reserves in the region are estimated at 31.3 billion barrels, representing $28 \%$ of the continent's total reserves. There is also huge agriculture, forestry and hydroelectric power potential. Climatic conditions and the availability of quality arable land favour agricultural development. It has the continent's largest hydro-electric potential. The immense water network density accounts for $60 \%$ of Africa's hydropower potential. According to another report by COEGA (2016), ECCAS as a region in 2015 accounted for $14 \%$ of the sub-Saharan Africa's economy. The ECCAS region economy grew by $5.3 \%$ on average and improved from US\$127.6 billion in 2005 to US\$219.4 billion in 2015. Without doubt the CAR (Central Africa Region) is endowed with bounty of natural resources. Notwithstanding, inconsistency and instability in states under ECCAS remain a major conundrum that has halted the evolvement of the community.

To Byiers (2017), while ECCAS was dormant from 1992 until 1998, ECCAS was 'revived' in 1999, having signed the initial protocol on relations between the African Union and the Regional Economic Communities (RECs). The renewed mandate gave ECCAS a security mandate through the Council for Peace and Security in Central Africa (COPAX), and a mandate to form a Free Trade Area (FTA) as part of the African Economic Community (AEC), as foreseen under the Abuja Treaty. As noted in a report of United Nations conference on Trade and development (UNCTAD 2009), Africa regional integration was pursued to enhance political unity at Pan African level and as a means to foster economic growth 
$9^{\text {th }}$ INTERNATIONAL CONFERENCE ON

MANAGEMENT , ECONOMICS AND HUMANITIES

26-28 July, 2019

London, United Kingdom

and development. This paper shall examine the objectives, challenges and evaluate the performance of ECCAS as an organization.

\section{Understanding Economic Regionalism in Africa}

In order to discuss economic regionalism in Africa, two dimensions have been examined in order to analyze a suitable theory for the research according to International Relations and International Economics.

Neo-liberalism theory has been selected in the area of International relations discipline. It was adopted in order to understand ECCAS as an organization that was late in grasping the importance of cooperation between member states.

Neoliberals begin with assertions of acceptance of several key realist propositions; however, they end with a rejection of realism and with claims of affirmation of the central tenets of the liberal institutionalism tradition. To develop this argument, neoliberals first observe that states in anarchy often face mixed interests and, in particular, situations which can be depicted by Prisoner's Dilemma (Axelrod and Keohane, 1986). According to Grieco, (1988)in the game, each state prefers mutual cooperation to mutual non-cooperation (CC $>D D$ ), but also successful cheating to mutual cooperation $(D C>C C)$ and mutual defection to victimization by another's cheating ( $D D>C D)$; overall, then, $\mathrm{DC}>\mathrm{CC}>\mathrm{DD}>\mathrm{CD}$. In these circumstances, and in the absence of a centralized authority or some other countervailing force to bind states to their promises, each defects regardless of what it expects the other to do. Going by the theory it is important to note that during the dormant period of ECCAS, member states were in a state of anarchy, with war, coup d'état and political instability (Ayangafac, 2008).

To neo-liberals War was a cancer on the body politic. But it was an ailment that human beings, themselves, had the capacity to cure. The treatment which liberals began prescribing in the eighteenth century had not changed: the 'disease' of war could be successfully treated with the twin medicines of democracy and free trade. Democratic processes and institutions would break the power of the ruling elites and curb their propensity for violence. Free trade and commerce would overcome the artificial barriers between individuals and unite them everywhere into one community (Burchill, 2005).

Neo-liberalism's claims about cooperation are based on its belief that states are atomistic actors. It argues that states seek to maximize their individual absolute gains and are indifferent to the gains achieved by others. Cheating, the new theory suggests, is the greatest impediment to cooperation among rationally egoistic states, but international institutions, the new theory also suggests, can help states overcome this barrier to joint action (Grieco, 1988). 


\title{
$9^{\text {th }}$ INTERNATIONAL CONFERENCE ON
} MANAGEMENT , ECONOMICS AND HUMANITIES

\author{
26-28 July, 2019 \\ London, United Kingdom
}

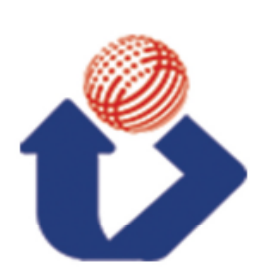

Liberal institutionalisms believe that cooperation between states can and should be organized and formalized in institutions (Stein, 2008). 'Institutions' in this sense means sets of rules which govern state behavior in specific policy areas, such as the Law of the Sea. The revival of ECCAS in 1999 was a turning point for member states to embrace the importance of cooperation in order to attain prosperous economic and political stability.

Liberal institutionalisms on the other hand, believe international relations need not be a zero-sum game, as many states feel secure enough to maximize their own gains regardless of what accrues to others. Mutual benefits arising out of cooperation are possible because states are not always preoccupied with relative gains (Burchill, 2005).

The basic economic integration theory of Bela Balassa in the area of international economics was selected. It was adopted because he produced in 1961 his own model about the European integration that was rather following its evolution ever since - a five steps process: (i) free exchange area, (ii) customs union, (iii) common market, (iv) economic union, (v) economic and monetary union (Balassa, 1961), which ECCAS is working towards achieving. Moreover, multiple memberships have hampered economic integration in two ways. First, by preventing consistencies and compatibilities, as well as inhibiting coordination and harmonization of activities like customs union, free trade, single market, monetary union and single/common currency directly. The second is indirectly, by forcing members to dissipate scarce human and financial resources in seeking to service different regional communities and implementing differing, contradicting and conflicting treaties (Economic Commission for Africa, 2004).

In addition, multiple membership has also bedeviled the long running and still incomplete negotiations between several disparate groups of member states and the EU over the establishment of regional Economic Partnership Agreements (EPAs). Overlapping membership to different trade regimes and instruments risk trade deflection, and dealing with them posed legal and administrative challenges to member states. Whilst, one major problem of subgroupings in the African regional economic communities is that it undermines the commitment and allegiance of those African states towards the regional bodies (Aniche, 2015).

From the kickoff, ECCAS were faced with difficulties typical of most African regional institutions, particularly the competitive and duplicative nature of regional integration. The diversity of regional integration institutions is seen in the fact that most of the members of ECCAS are also members of Central African Economic and Monetary Community (CEMAC) and Economic Community of the Great Lakes Countries (CEPGL); Angola and the Democratic Republic of Congo are members of ECCAS and Southern African Development Community (SADC); Burundi and Rwanda are members of ECCAS, CEPGL, and the East African Community (EAC). These institutional overlap have limited the capacity of established institutions to foster collective efforts toward effective harmonization and integration (Gankou and Ntah 2008). More critically, even though ECCAS is the largest regional institution in Central Africa, CEMAC has advanced further toward regional integration because it has established 
more effective mechanisms such as coordinated and preferential trade reforms; a common currency zone known as the Communuate Financier de l'Afrique (CFA); a regional central bank; and a regional development bank (Gankou and Ntah 2008). Ironically, the AU has recognized ECCAS, instead of CEMAC, as the foundation for the African Economic Community (AEC) in Central Africa.

Throughout the first decade, ECCAS adopted a trade liberalization program that was to be implemented gradually, starting with tariff reductions and the elimination of non-tariff barriers to intra-ECCAS trade. Conversely, not much progress has been made in implementing any element of this trade liberalization program. During the 1990s, ECCAS suffered from a period of inactivity due to conflicts, the absence of regional mechanisms for conflict prevention and management, and the low level of commitment among members (Awoumou 2008). ECCAS has achieved little in the areas of its core mandate of regional economic integration and peace and security.

Optimistically, a regional economic integration that embraces all the $54 \mathrm{AU}$ member states endowed with human resources of a growing and youthful population of over a billion people, if it succeeds in dismantling all trade barriers (TBs) and non-trade barriers (NTBs) to intra-African trade will unlock the continent's immense development potentials, boost its trade performance and integration into the global trading system, and reduce the continent's heavy dependence on aid for development. Thus, it has been noted that achievement of a successful regional integration will require the removal of tariffs, the establishment of common rules of origin, the harmonization and simplification of customs regulations and procedures, and the elimination of NTBs to intra-African trade. This will lead to a significant growth and sustainable development just as the creation of the COMESA FTA led to a six-fold increase in intra-COMESA trade between 2000 and 2010. In summary, therefore some of the benefits, opportunities and prospects of regional integration in Africa include larger markets, economic cooperation, trade facilitation, etc. (Okafor and Aniche, 2017).

In short, some of these challenges, constraints, obstacles, and difficulties militating against successful African integration include neo-colonial ties, politico-ideological differences, exportoriented primary products of African states; disparity in size and development of African states; fear of domination or monopolization of benefits; adverse activities of MNCs operating in Africa; historical, political, economic and vertical linkages of African economies to Western economies; structural dependence of African economies to Western economies; intractable civil strife and the attendant refugee crises and internal displacements (Okafor and Aniche, 2017).

Historically, regional economic integration in Africa can be traced back to 1910 with the founding of Southern African Customs Union (SACU) by the countries of Botswana, Lesotho, Namibia, Swaziland and South Africa. Other economic cooperation includes East African Community (EAC), IGAD, CEN-SAD, Southern African Development Community (SADC), ECCAS, Economic Community of West African States (ECOWAS), and the Common Market for Eastern and Southern Africa (COMESA), Arab Maghreb Union (AMU) etc. 
Moreover, there is the planned African Economic Community (AEC), whose treaty was signed in 1991 referred to as the Abuja Treaty and it is expected by 2025 (lyoha, 2005). After prolonged foot dragging by the strongest economy in the continent, on 7 July 2019 at the 12th Extraordinary Session of African Union on African Continental Free Trade Agreement (AfCFTA) Nigeria alongside Benin signed the Agreement, leaving Eritrea as the only state yet to sign this agreement. The AfCFTA will bring together all 55 member states of the African Union covering a market of more than 1.2 billion people, including a growing middle class, and a combined gross domestic product (GDP) of more than US\$3.4 trillion. In terms of numbers of participating countries, the AfCFTA will be the world's largest free trade area since the formation of the World Trade Organization. Estimates from the Economic Commission for Africa (UNECA) suggest that the AfCFTA has the potential both to boost intra-African trade by 52.3 percent by eliminating import duties, and to double this trade if non-tariff barriers are also reduced (Trade Law Centre, 2019).

The eight regional economic communities within the African Union framework that serve for the implementation and monitoring of New Partnership for Africa's Development (NEPAD) programs are as follows: the Community of Sahel-Saharan States (CEN-SAD), the Common Market for Eastern and Southern Africa (COMESA), the East African Community (EAC), the Economic Community of Central African States (ECCAS), the Economic Community of West African States (ECOWAS), the Intergovernmental Authority for Development (IGAD), the Southern African Development Community (SADC), the Arab Maghreb Union (UMA) (NEPAD 2011).

As the Community of Sahel-Saharan States and the Common Market for Eastern and Southern Africa spread their activities to other regions, the stratification embraced by the NEPAD Heads of State and Government Implementation Committee into north, south, west, central, and east will be followed to avoid coinciding situations.

\section{Objective of ECCAS as an Organization}

The Treaty establishing ECCAS was adopted in 1985 with the objectives of adopting, coordinating and harmonizing common policies in order to boost the economic development of member states through a gradual and progressive establishment of a common market and the suppression of barriers among Central Africa states members (Fotso, 2014). Ndomo (2009), on the other hand enumerated some of the mandates expected from ECCAS such as, developing physical, economic and monetary integration of the sub-region; to enhance the region's capacity to maintain peace, security and stability and develop capacity for analysis, policy interventions, entrepreneurial initiatives, communication and collective negotiation. The scholar further stated that ECCAS took the mandate of implementing NEPAD's program of action in Central Africa. It also has the additional responsibility of coordinating the sub region's strategies for achieving the MDGs (Millennium Development Goals).

According to united nation the following are specific objectives of ECCAS; 


\title{
$9^{\text {th }}$ INTERNATIONAL CONFERENCE ON MANAGEMENT , ECONOMICS AND HUMANITIES
}

\author{
26-28 July, 2019 \\ London, United Kingdom
}

1.The elimination of customs duties and any other charges having an equivalent effect on import and export between member states;

2.The abolition of quantitative restrictions and other trade barriers

3.The establishment and maintenance of an external common customs tariff;

4.The establishment of trade policy vis-à-vis third states;

5.The progressive removal of barriers to the free movement of persons, goods, services and to the capital and to the right of establishment;

6.The harmonization of national policies in order to promote community activities, particularly in industry, transport and communications, energy, agriculture, natural resources, trade, currency and finance, human resources, tourism, education, culture, science and technology;

7.The establishment of a cooperation and development fund;

8.The rapid development of states which are landlocked, semi- landlocked, island or part- island and/or belong to the category of the least advance countries;

9.Any other joint activities which can be undertaken by member states for achieving community aims.

ECCAS has placed emphasis on an intergovernmental cooperation framework, with national interests taking prominence over regional concerns (Gankou and Ntah 2008).

The significance accorded to state sovereignty is reflected in the institutional arrangements that give prominence to heads of state of member countries. The core institutions of ECCAS are the Authority of Heads of State and Government, Council of Ministers, Court of Justice, General Secretariat, Consultative Committee, and Specialized Technical Committees. As the main decisionmaking body, the Authority has extensive powers that include the final approval of all policy matters recommended by the Council (ECCAS 1983). Given that the Authority is vested with the power to overturn or reject policy proposals, the decisions of the Council and other institutions are severely curtailed. Operationally, there are infrequent meetings of the Authority and the Council, engendering institutional inertia that has greatly impeded the implementation of decisions.

Like ECOWAS, ECCAS aims to promote regional economic cooperation among its member states in Central Africa.19 Created in 1983, the community started formal operation in 1985. The community became active only in 1999 when the treaty recognizing it as a REC within the African Economic Community was signed. 
Among the various RECs in Africa, progress in the functioning of ECCAS has lagged considerably behind for a host of reasons, including the series of conflicts in the Great Lakes region; weak financial commitments of member states to support the common cause of the community; overlapping membership of member states in other regional blocs, which also make it difficult for member states to fully honor their financial commitments; weak commitments to regional policy partly because of overlapping membership in other regional groupings; and a fairly heterogeneous group by way of language and culture (Economic Commission for Africa, 2010). Although all members of the Economic and Monetary Community of Central Africa region are members of ECCAS, there are members in ECCAS, such as Burundi, that have joined the East African Customs Union (Tuffour et al., 2016).

Sticking to the level of integration in ECCAS, the region has not been able to do much. In 2004, ECCAS set up a free trade area with the hope of transforming it into a customs union by 2008. This, however, has been unsuccessful. Implementation of the free trade area in the ECCAS region is yet to gain wider cooperation from all member states as bottlenecks still persist in some countries (Elowson and Wiklund 2011).

\section{Evaluating Performance of ECCAS}

Studies on ECCAS have shown that the community is yet to attain the objectives set up by the 1980 Lagos Plan of Action. Ndomo (2009) posits that ECCAS is defined or classified by being weak institutionally and organizationally in terms of capacity. However, its member states signed a free trade area agreement in 2004 that was to come into force in 2006. This partly reflected the member states' lack of political will to surrender aspects of their respective national sovereignty to the supranational regional body which reflects the inherent weakness and indecisiveness of states in conflict. Inter- regional trade only stands at around 2 percent of its total trade volume. Also due to pervasive conflicts, ECCAS has failed to mobilize the necessary resources to execute its mandate. According to the report published by African Development bank (2011), economically, Central Africa performed relatively well over the last ten years, with an average growth rate of about $6.2 \%$ during the 1999-2009 period, with 7.3\% on average in the six oil-producing countries (Angola, Cameroon, Congo, Gabon, Equatorial Guinea and Chad) and $4.7 \%$ in other countries. Economic growth in the region, which is above the African average (4.8\%), was generally marked by higher exports of crude oil and mining products making it possible to finance non-oil activities. Accordingly, the region's economy remains vulnerable to external shocks, mainly on account of its heavy dependence on oil production. In the United Nations Conference on Trade and Development 2016 the GDP, GDP per capita, area (sq. km), population, import and export of ECCAS are US\$257.8 billion US\$1631.4 6.5 million sq.km 158.3 million US\$ 63.7 billion US\$108.1 billion respectively (Unctad 2016).

To reverse this trend, the United Nations Economic Commission for Africa (UNECA) took the lead in the late 1990s to resuscitate ECCAS by providing technical assistance to establish a self-sufficient financing mechanism and a Free Trade Area (FTA). ECCAS adopted a recovery and revitalization 


\title{
$9^{\text {th }}$ INTERNATIONAL CONFERENCE ON MANAGEMENT , ECONOMICS AND HUMANITIES
}

\author{
26-28 July, 2019 \\ London, United Kingdom
}

program based on the development of physical, economic, and monetary integration at the start of the new millennium at a summit in Malabo. Nonetheless, ECCAS has continued to receive international backing as the principal integration body in Central Africa (Ikome 2009).

Africa Regional Integration Index Report (2016) is made up of five dimensions, which are the key socio-economic categories that are fundamental to Africa's integration. Sixteen Indicators (based on available data), which cut across the five Dimensions, have been used to calculate. The Index indicated that ECOWAS has higher than average REC scores across the Dimensions of Free movement of people and Financial and macroeconomic integration. While ECCAS is the second successful in terms of financial and macroeconomic integration. SADC has higher than average REC scores across the Dimensions of Regional infrastructure, Free movement of people and Financial and macroeconomic integration. Whereas ECCAS is the third in terms of regional integration behind ECOWAS.

According to Babani and Can (2019) one of the African regional economic community ECOWAS achieved approval of a common passport for the West African region. It is also another achievement of ECOWAS that The legendary women traders of West Africa have taken advantage and acted as motors of regional integration. These can be an example to the improvement of regional economic integration from Africa to ECCAS.

Africa Regional Integration Index Report (2016) mentioned Angola and Democratic Republic of the Congo are the principal contributors to wealth creation in the region with $36 \%$ and $19 \%$ of regional GDP respectively, but are not top performers. Whereas Cameroon is in first place and is the third contributor of regional GDP.

In the last decade, ECCAS launched a number of initiatives, including the Central African Energy Pool (PEAC) to coordinate energy issues, a plan to coordinate transport infrastructure, and the initiation of a FTA that would be established over 4 years, leading to a single regional market as part of the revitalization process (Awoumou 2008).

ECCAS has dealt with various challenges since its establishment; the community is termed to have performed very poorly but with recent revival of the community, there has been positive and progressive achievement vis-à-vis its political and economic development.

\section{Challenges Faced by ECCAS}

The community's progress was largely impeded by financial and technical bottlenecks resulting from the failure of member states to pay their fees regularly and to provide sufficient resources and capacities, as well as the rise of crises and conflicts in the region. As a result, contacts with AEC (African Union's economic) remained undeveloped. In addition, the conflicts that affected most member states during the 1990s paralyzed economic cooperation and exchange within the 
community. Between 1992 and1998, the community's activities were disrupted and the headquarters in Libreville, the Gabonese capital, remained non-operational (Meyer, 2011).As noted in a report by International Democracy watch, in 1992, ECCAS entered a state of complete inactivity for several years. While the financial bottlenecks largely hindered the proper functioning of regional institutions and implementation of policies and activities, the conflict proneness of the region and especially the engagement of some members on opposite sides in the DRC war paralyzed the economic cooperation and exchange within the Community (Meyer, 2015).

To Meyer (2015), during the 1990s, the rise of political instability, crises and conflicts in majority of Central African countries, as well as the engagement of some member states on opposite sides in the Great Lakes wars brought an additional challenge to regional cooperation. Thus, from 1992 to 1998 , the community went through a period of inactivity and paralysis, which is often referred to as ECCAS' hibernation.

According to Africa News Agency (2017), many reports say that Central Africa gives a home to great economic development potential, vast mineral and metal deposits, oil reserves from the Gulf of Guinea to Chad and Cameroon, massive water resources in the Congo Oubangui-Sangha basin, the Lack Chad basin, and the second largest tropical forest area deemed to be the second lung of the planet. Despite all these, we wonder why the region stills the poorest in the continent, slowest of the sub-regions in terms of economic growth. Gonga Koyang Feouda, former Chad National Focal Point to the ECCAS explains the reason behind the region poverty that the French colonization has had a negative impact on the region, and most of the region current leaders are corrupted.

In a report on regional integration paper (2011) funded by African Development Bank stated that weak basic infrastructure compared with the continents other regions is also one of the challenges of this region. Specifically, the inadequate interconnection of national transport networks between Central African countries is an obstacle to economic and physical integration and the development of countries in the region. Similarly, electricity and water supply difficulties impede the emergence of a dynamic and competitive private sector.

Central Africa is one of the continent's most fragile and vulnerable regions, having witnessed a large number of all the coups d'état, crises and conflicts that have taken place in Africa since 1990. Although the ECCAS community also includes countries that are relatively stable, without any major political crises since their independence like Gabon or Cameroon (Meyer, 2015).

In a nutshell the continued insecurity, combined with lack of political transition in the sub-region, has had profound effects on development trajectories, destroying infrastructure, social capital and markets, and leaving many of the countries in the region with weakened institutions poorly equipped to address significant ensuing post-conflict reconstruction challenges (United Nation Development Programme, 2017). 


\title{
$9^{\text {th }}$ INTERNATIONAL CONFERENCE ON MANAGEMENT , ECONOMICS AND HUMANITIES
}

\author{
26-28 July, 2019 \\ London, United Kingdom
}

In order to collective combat the challenges of insecurity, on the 28th July 2018, a combined meeting of ministers in preparation for the Joint Summit of Heads of State and Government between ECCAS and ECOWAS on Peace, Security, Stability and the Fight against Terrorism and Violent Extremism was held in Togo. Some of the agendas of the meeting were the presentation of report of the ECOWAS-ECCAS experts' meeting on Peace, Security, Stability and the Fight against Terrorism and Violent Extremism, and a consideration and adoption of the draft Declaration of the Joint Summit of Head of States and Governments (ECOWAS-ECCAS council report 2018).

\section{Conclusion}

Regional integration is not only seen as a powerful tool that promotes inclusive growth and political stability, but also addresses the challenges of global economic, technological and ecological change. On this basis, African leaders and institutions are making enormous efforts to promote regional integration. However, statistics on the state of African integration are not impressive. The challenges to be overcome are immense and in order to strengthen this integration, the process in ECCAS stumbles over critical complexities especially as the area lacks cultural affinities moreover the existing levels of integration are promoted from outside the region and not sustained from within.

Regionalism in sub-Saharan Africa remains the most vital African resourcefulness for tackling the essential problems of Afri-can economy. Therefore, African governments must display better political will towards the revival of present sub-regional and regional communities into more worthwhile organizations that can address the issues of globalization, underdevelopment, poverty, ignorance and diseases.

ECCAS remain a vital organization among the eight recognized economic community in Africa. But so far, the success of ECCAS is relatively poor. This was as a result of war, coup d'état and conflicts among others. Going by the study it could be concluded that ECCAS is yet to attain tangible success compare to other recognized organizations in Africa.

There is need for African Union to impose certain criteria on member states of ECCAS, in order to attain concrete success. There is urgent need for ECCAS to adopt principle and framework that can guide member states in economic development. Hence, a pragmatic approach on amendment of ECCAS laws, to be updated to meet contemporary need of members. 


\section{$9^{\text {th }}$ INTERNATIONAL CONFERENCE ON MANAGEMENT , ECONOMICS AND HUMANITIES}

26-28 July, 2019

London, United Kingdom

\section{References}

[1]Africa News Agency. (2017, January 24). ECCAS 2025: Racing Against the Time. Available: www.africanewsagency.fr: http://www.africanewsagency.fr/2017/01/24/eccas-2025-racingagainst-the-time-2/?lang=en

[2]African Union Commission (AUC), African Development Bank (AfDB) and the Economic Commission for Africa (ECA).Africa Regional Integration Index Report 2016, the 2016, pp. 17-46

[3]Aniche, E.T., Okeke, V.O.S. and Ukaegbu, V.E. (2009). Regional economic integration in Africa: A comparative study of ECOWAS and SADC. International Journal of Africa Culture, Politics and Development, 4(2), 82-101.

[4]Axelrod, R. and Keohane, R. O. (1986). Achieving Cooperation underAnarchy: Strategies and Institutions. In K. A. (eds), Cooperation under Anarchy (pp. 231). NewYork: Princeton.

[5]Ayangafac, C. (2008). Political Economy of Regionalisation in Central Africa. Institute for Security Studies. Pretoria. pp. 109-138

[6]Babani, U. M. and Can, N. Achievements of Non-State Actors at Diplomacy: A Lesson from ECOWAS International Journal of Social Sciences Volume 3 Issue 2019, pp. 24-44.

[7]Balassa B. (1961) Towards a Theory of Economic Integration, Kyklos International Review for Social Sciences, pp. 17.

[8]Burchill, S. (2005). Liberalism . In S. L.-S. Burchill, Theories of International pp. 55-64. New York: Palgrave Macmillan.

[9]Byiers, B. (2017). Understanding regional economic policies in Central Africa : Struggling to integrate in an intertwined region. European Centre for Development Policy managemnt .

[10]COEGA. (2016). The ECCAS Region: The Belt of Africa . Cape Town: COEGA Development Corporation.

[11]Economic Commission for Africa, (2004). Assessing Regional Integration in Africa Addis Ababa, pp. 9-11. Available:https://www.uneca.org/sites/default/files/PublicationFiles/aria1english_full.pdf

[12]Economic Commission for Africa, (2010). Assessing Regional Integration in Africa IV: Enhancing Intra-African Trade, pp. 14-16. Availabale:https://www.unece.org/fileadmin/DAM/trade/TF_JointUNRCsApproach/ECA_IntraAfric anTrade.pdf 


\section{$9^{\text {th }}$ INTERNATIONAL CONFERENCE ON MANAGEMENT , ECONOMICS AND HUMANITIES}

[13]ECOWAS-ECCAS (2018). Council Report on Peace, Security, Stability and the Fight Against Terrorism and Violenct Extremism, Lome. pp 1-8.

[14]Elowson, C. and Wiklund, C.H. (2011). Regional Integration for Peace and Security in Central Africa ECCAS Capabilities in Peace and Security. Stockholm. pp. 24-26. Available: https://www.foi.se/rest-api/report/FOI-R--3244--SE

[15]Fotso, A. D. (2014). The potential effects of the ECCAS Free Trade Area on Trade Flows . Munich Personal RePEc Archive, 2.

[16]Grieco, J. M. (1988). Anarchy and the limits of cooperation:a realist critique of the newest liberal institutionalism. World Peace Foundation and the Massachusetts Institute of Technology, pp. 487.

[17]Hansohm D. and Shilimela R. (2006). Progress in economic integration within SADC. In A. W. Bösl, Monitoring regional integration in southern Africa: Yearbook Vol 6 (pp. NP). Stellenbosch: Trade law centre for Southern Africa.

[18]International Democracy watch . (n.d.). Economic Community of Central African States. Available: http://www.internationaldemocracywatch.org/index.php/economic-community-ofcentral-african-states-

[19]Meyer, A. (2011, NM ND). Peace and security cooperation in Central Africa Developments, Challenges and Prospects. Uppsala, Uppsala, Sweden.

[20]Meyer, A. (2011,). Economic Community of Central African States.First International Democracy Report. International Democracy Watch. pp. 2-5.

Availabe: http://www.internationaldemocracywatch.org/attachments/457_ECCAS-meyer.pdf

[21]Meyer, A. (2015). Preventing conflict in Central Africa ECCAS caught between ambitions, challenges and reality. Institute for Security Studies.

[22]Ndomo, A. (2009). Regional Economic Communities in Africa A Progress Overview. German Corporation for Technical Cooperation (GTZ).

[23]NEPAD. (2011). AU/NEPAD African Action Plan 2010-2015: Advancing Regional and Continental Integration Together through Shared Values. Johannesburg, pp.11. Available: http://www.oecd.org/investment/investmentfordevelopment/47693615.pdf

[24]NEPAD. (2015). Strengthening the Institutional Capacity of the Economic Community of Central African States (ECCAS). Midrand: NEPAD Planning and Coordinating Agency. 


\section{$9^{\text {th }}$ INTERNATIONAL CONFERENCE ON MANAGEMENT , ECONOMICS AND HUMANITIES}

26-28 July, 2019

[25]Ntembe, A \& Tawah, R . (2012). The determinants of trade in the Central African Economic and Monetary Union. Research in Business and Economics Journal, pp. 2-3.

[26]Stein A. A.(2008). Neoliberal Institutionalism, The Oxford Handbook of International Relations. . New York: Oxford University Press, pp. 201-221

[27]Trade Law Centre, African Continental Free Trade Area (AfCFTA) Legal Texts and Policy Documents, 2019. Available: https://www.tralac.org/resources/our-resources/6730-continentalfree-trade-area-cfta.html

[28]Tuffour J. A., Balchin N., Calabrese L. and Parra M.M (2016). Trade Facilitation Andeconomic Transformation In Africa. African Transformation Forum. pp.16. Available:

https://set.odi.org/wp-content/uploads/2016/03/SET-ACET-ATF-Trade-Facilitation-Paper.pdf

[29]UNCTAD. (n.d.). (2009). Trade and Development Report: Responding to the global crisi, Climate change mitigation and development. Geneva : United Nations .

[30]UNCTAD. (n.d.). (2016). Trade and Development Report: Responding to the global crisi, Climate change mitigation and development. Geneva : United Nations .

[31]United Nation Development Programme. (2017). Central Africa: A Sub-Region falling BEhind? Geneva: United Nation.

[32]United Nations . (n.d.). ECCAS - Economic Community of Central African States. Available:www.uneca.org: https://www.uneca.org/oria/pages/eccas-economic-community-centralafrican-states 